Hapni Laila Siregar, Ramli/ Ta'dib: Jurnal Pendidikan Islam, Vol. 9 No. 1 (2020) 116-129

ISSN 1411-8173 | E-ISSN 2528-5092

https://ejournal.unisba.ac.id/index.php/tadib/article/view/6339

\title{
DEVELOPMENT OF INTEGRATED CHARACTER EDUCATION MODELS IN PAI LEARNING AT UNIVERSITY
}

\author{
Hapni Laila Siregar ${ }^{1}$, Ramli $^{2}$ \\ Universitas Negeri Medan \\ Email: ${ }^{1}$ hapnilai@gmail.com, ${ }^{2}$ ramli2019@gmail.com
}

DOI: https://doi.org/10.29313/tjpi.v9i1.6339

Submitted: June 16th, 2020. Approved: June 29th, 2020. Published: June 29th, 2020

\begin{abstract}
Abstrak
Penelitian ini bertujuan untuk mengembangkan model pendidikan karakter terintegrasi dalam pembelajaran PAI di Perguruan Tinggi. Karakter-karakter yang diintegrasikan dalam pembelajaran PAI dalam penelitian ini mengacu kepada karakter-karakter yang dibutubkan di abad ke-21. Seorang mahasiswa yang berkarakter akan mampu berperan serta secara positif baik sebagai pribadi, sebagai angota keluarga, anggota masyarakat, warga negara, maupun warga dunia. Penelitian ini menggunakan pendekatan kualitatif dan kuantitatif dengan metode penelitian R $\sigma D D$ dari Borg \& Gall. Teknik pengumpulan datanya menggunakan observasi, wawancara, angket dan skala sikap. Teknik analisis data kualitatif merujuk pada tiga langkah dari Miles \& Hubberman. Sementara teknik analisis data kuantitatif menggunakan uji Wilcoxon. Penelitian dilakukan di beberapa jurusan di Universitas Negeri Medan pada semester genab Tahun Akademik. 2018-2019. Penelitian ini menghasilkan temuan bahwa model pendidikan karakter terintegrasi dalam pembelajaran PAI dalam penelitian ini efektif mengembangkan karakter mahasiswa terutama karakter keatif, kerja keras dan mandiri, serta efektif mengembangkan keterampilan berkreativitas Islami dan berdak.wah virtual.
\end{abstract}

Kata Kunci: Pengembangan Model; Pendidikan Karakter; Pembelajaran PAI.

\begin{abstract}
This study aims to develop an integrated character education model in Islamic Education learning in tertiary institutions. The characters integrated in Islamic Education learning in this study refer to the characters needed in the 21st century. A student with character will be able to participate positively both as individuals, as family members, members of society, citizens, and citizens of the world. This study used a qualitative and quantitative approach with the ReD research method from Borg \& Gall. Data collection techniques using observation, interviews, questionnaires and attitude scales. Qualitative data analysis techniques refer to the three steps of Miles \& Huberman. Meanwhile, the quantitative data analysis technique used the Wilcoxon test. Research was conducted in several departments at Medan State University in the even semester of the 2018-2019 Academic Year. This study resulted in the finding that the integrated character education model in Islamic Islamic education in this study was effective in developing student character, especially creative character, hard work and independence, and was effective in developing Islamic creativity and virtual da'wah skills.
\end{abstract}

Keywords: Model Development; Character building; PAI learning. 


\section{PENDAHULUAN}

Pendidikan karakter harus terus menjadi prioritas dalam dunia pendidikan Indonesia karena jika melihat kondisi saat ini, banyak kejadian negatif berupa perilaku-perilaku tidak terpuji yang terjadi di masyarakat. Pengaruh budaya luar yang negatif perlahan tapi pasti terus menggerus karakter anak bangsa. Pendidikan Tinggi merupakan fondasi pembangunan, yang diharapkan mampu menghasilkan lulusan yang berkualitas dan berkarakter. Untuk dapat menghasilkan lulusan yang berkualitas, berkarakter terpuji, dan memiliki sikap mental yang kuat dan tangguh, pendidikan karakter harus terintegrasi dalam semua mata kuliah di perguruan tinggi (Budimansyah, 2014) tidak terkecuali dalam mata kuliah Pendidikan Agama Islam (PAI).

Di Perguruan Tinggi, PAI merupakan bagian dari mata kuliah wajib umum yang berorientasi pada pembentukan nilai-nilai keimanan dan ketaqwaan kepada Allah SWT serta akhlak mulia. Misi utama PAI adalah membina kepribadian mahasiswa secara utuh dengan harapan kelak mereka akan menjadi ilmuwan yang beriman dan bertakwa kepada Allah Swt serta mampu mengabdikan ilmunya untuk kesejahteraan umat manusia (Syahidin, Alma, Rahmat, AF, \& Abdussalam, 2009). Mengingat misi tersebut seyogyanya perkuliahan PAI disampaikan melalui proses pendidikan secara integral, menyeluruh dan berkesinambungan, karena akan membentuk karakter yang baik dan mempertahankannya sampai akhir hayat.

Banyak penelitian yang menunjukkan masih belum optimalnya pengintegrasian pendidikan karakter dalam pembelajaran PAI, antara lain: 1) pembelajaran PAI di Perguruan Tinggi masih bersifat indoktrinatif padahal Islam bukanlah hanya sebuah sistem keyakinan yang terbentuk oleh dogma-dogma sebagai fakta historis (Nurudin, 2007). 2) Para pengajar PAI masih sering memaknai PAI sebatas hafalan dan pemahaman, atau hanya berkutat pada hal-hal normatif (Mulyana, 2013) yang seringkali tanpa ilustrasi konteks sosial budaya. 3) Penyelenggaraan pembelajaran PAI di Indonesia belum sepenuhnya mengembangkan kemampuan berpikir rasional yang kuat dan kemandirian (Tan, 2011).

Berdasarkan semua hal di atas, maka upaya pengembangan model pendidikan karakter terintegrasi dalam pembelajaran PAI sangat urgen untuk dilakukan. Berdasarkan latar belakang di atas, masalah penelitian ini dapat dirumuskan: bagaimanakah model pendidikan karakter terintegrasi dalam pembelajaran PAI di Perguruan Tinggi? Produk yang diharapkan dari penelitian ini adalah model pendidikan karakter terintegrasi dalam pembelajaran PAI yang mampu mengembangkan karakter mahasiswa khususnya karakter-karakter yang dibutuhkan di abad ke-21 sekarang ini. Model adalah suatu kumpulan asumsi atau postulat yang berusaha menetapkan konsepsi kerja yang digeneralisasikan, yang menerangkan data empiris atau relasi empiris (Chaplin, 1989, hal. 306). Menurut Komaruddin dalam (Sagala, 2007, hal. 175) "model diartikan sebagai kerangka konseptual yang digunakan sebagai pedoman dalam melakukan kegiatan.” Model pembelajaran PAI berbasis proyek video Islami adalah serangkaian aktivitas pembelajaran PAI 
yang dilakukan mahasiswa untuk menghasilkan video-video Islami yang menarik, informatif dan bermakna yang bertujuan untuk membangun karakter mahasiswa di abad ke-21 serta membangun keterampilan mahasiswa dalam berkreativitas Islami. Pemilihan pembuatan video Islami sebagai tugas proyek PAI ini dilatar belakangi oleh pentingnya memanfaatkan kemajuan teknologi informasi untuk berkreativitas islami, serta adanya trend digital life di abad ke-21 ini yang ditandai dengan semakin massifnya penggunaan internet. Menurut Dulwahab, 2010 kegiatan mengakses internet kini telah menjadi gaya hidup manusia modern. Data Internet World Stats 2018 memperlihatkan bahwa 132,7 juta orang dari keseluruhan jumlah penduduk Indonesia yang kini berjumlah 265,4 juta orang adalah pengguna internet (Sholihin, 2018). Artinya sekitar 50\% penduduk di Indonesia sudah menggunakan internet, dimana terjadi peningkatan dalam jumlah pengguna sosial media yaitu sekitar 49\% dari populasi Indonesia ("Inilah Data Pengguna Internet di Indonesia 2018, 49\% Penggila Medsos,” 2018). Jumlah ini juga sekaligus menempatkan Indonesia pada posisi kelima pengguna internet terbesar di dunia setelah China, India, Amerika Serikat dan Brazil (Buol, 2018).

Berdasarkan hal di atas, maka pemanfaatan kemajuan media, informasi dan tekonologi dalam pembelajaran PAI di perguruan tinggi mendesak untuk dilakukan. Hal ini senada dengan pendapat Giddens, 1990 penggunaan media teknologi dalam pembelajaran agama Islam di era digital ini merupakan sebuah keharusan karena modernisasi tidak bisa dihindarkan. Menurut Yousif, 2001 terdapat hubungan antara teknologi informasi dan Islam. Walaupun Qur'an bukanlah suatu buku teks ilmiah namun Qur'an merupakan petunjuk yang mengandung prinsip-prinsip umum yang berlaku sepanjang masa dan universal, termasuk petunjuk yang mengandung prinsip-prinsip universal ilmu pengetahuan yang merupakan domain utama dari teknologi informasi. Sehingga dengan mengimplementasikan teknologi informasi khususnya internet untuk Islam, berarti menerapkan prinsip-prinsip Islam.

\section{METODE PENELITIAN}

Tahapan pengembangan model pendidikan karakter terintegrasi dalam pembelajaran PAI dalam penelitian ini adalah sebagai berikut: Tahap pertama yaitu studi literatur dan studi lapangan (analisis kebutuhan). Berdasarkan kajian teori dan hasil penelitian pendahuluan, dirancang model pembelajaran PAI yang diasumsikan mampu mengembangkan karakter mahasiswa, yaitu model pembelajaran PAI berbasis proyek video Islami. Kemudian dilakukan uji validasi terhadap rancangan model oleh beberapa ahli yang dilaksanakan dalam suatu Forum Group Discussion (FGD). Perbaikan model kemudian dilakukan berdasarkan saran dan masukan dari ahli-ahli tersebut. Kemudian dilakukan uji coba model di tiga jurusan di Universitas Negeri Medan yaitu jurusan Pendidikan Teknologi Informasi dan Komunikasi (PTIK), jurusan Pendidikan Matematika dan jurusan Pendidikan Tata Busana. Ujicoba terbatas ini dilaksanakan dari tanggal 9 April - 23 Mei 2019, menghabiskan waktu selama 6 pekan.

Tulisan ini dikembangkan dari hasil pengembangan desain model dan hasil ujicoba model. Data hasil uji coba model 
dianalisis untuk mengetahui sejauh mana karakter terintegrasi dalam pembelajaran PAI setelah implementasi model. Teknik pengumpulan data yang digunakan dalam penelitian ini adalah angket dan wawancara.

\section{PEMBAHASAN}

\section{Pengintegrasian Pendidikan Karakter Dalam Pembelajaran PAI}

Karakter adalah "knowing the good, desiring the good, and doing the good (Lickona, 1992). Ada banyak konsep karakter yang perlu dikembangkan menurut para ahli. Konsep (good character) yang terdiri dari (ten essential virtues) dipopulerkan oleh Thomas Lickona, 2004. Sementara dikaitkan dengan watak kewarganegaraan Bronson, 1998 mempopulerkan karakter publik dan privat. Kementerian Pendidikan Nasional, 2010 mengidentifikasi 18 nilai karakter bangsa yang perlu dikembangkan yaitu religius, jujur, toleransi, disiplin, kerja keras, kreatif, mandiri, demokratis, rasa ingin tahu, semangat kebangsaan, cinta tanah air, menghargai prestasi, bersahabat/ komunikatif, cinta damai, gemar membaca, peduli lingkungan, peduli sosial, dan tanggung jawab. Sementara Gerakan Penguatan Pendidikan Karakter (PPK) yang dicanangkan Kementerian Pendidikan dan Kebudayaan, 2017 mengidentifikasi lima nilai utama karakter yang perlu dikembangkan sebagai prioritas, yaitu religious, nasionalis, mandiri, gotong royong, dan integritas. Penulis memilih 8 karakter sebagai titik fokus dalam penelitian ini yaitu jujur, bertanggung jawab, kerja keras, kreatif, mandiri, komunikatif, peduli sosial dan toleransi sebagaimana dapat dilihat dalam tabel di bawah ini:

Tabel 1

\begin{tabular}{|c|c|c|}
\hline \multicolumn{3}{|r|}{ Karakter Abad ke-21 } \\
\hline No & Jenis Karakter & Penjelasan Karakter \\
\hline 1 & Jujur & $\begin{array}{l}\text { Selalu dapat dipercaya dalam perkataan, tindakan dan } \\
\text { pekerjaan. }\end{array}$ \\
\hline 2 & Bertanggung jawab & Melaksanakan tugas dan kewajiban dengan sebaik-baiknya \\
\hline 3 & Kerja keras & $\begin{array}{l}\text { Berupaya sungguh-sungguh dalam mengatasi berbagai } \\
\text { hambatan belajar dan tugas, serta menyelesaikan tugas } \\
\text { sebaik-baiknya. }\end{array}$ \\
\hline 4 & Kreatif & $\begin{array}{l}\text { Melakukan sesuatu untuk menghasilkan cara atau hasil baru } \\
\text { dari sesuatu yang telah ada }\end{array}$ \\
\hline 5 & Mandiri & $\begin{array}{l}\text { Tidak mudah tergantung pada orang lain dalam } \\
\text { menyelesaikan tugas-tugas }\end{array}$ \\
\hline 6 & $\begin{array}{l}\text { Komunikatif/ } \\
\text { Bersahabat }\end{array}$ & $\begin{array}{l}\text { Senang berbicara, bergaul dan bekerja sama dengan orang } \\
\text { lain }\end{array}$ \\
\hline 7 & Peduli sosial & $\begin{array}{l}\text { Sikap dan tindakan yang selalu ingin memberi bantuan pada } \\
\text { orang lain dan masyarakat yang membutuhkan }\end{array}$ \\
\hline
\end{tabular}




\begin{tabular}{|l|l|l|}
8 & Toleransi & $\begin{array}{l}\text { Menghargai perbedaan baik itu perbedaan pendapat, sikap } \\
\text { dan tindakan orang lain, juga perbedaan agama, suku, } \\
\text { budaya dll }\end{array}$ \\
\hline
\end{tabular}

Dalam penelitian ini juga dua cara yaitu melalui materi PAI dan dikembangkan kemampuan menggunakan melalui pengalaman-pengalaman bermakna media, informasi dan teknologi untuk bermuatan karakter selama proses berkreativitas Islami, serta kemampuan pembuatan video Islami. Implementasi menyampaikan syiar-syiar Islam di internet model pembelajaran PAI berbasis proyek (dakwah virtual). Pengintegrasian karakter dalam model pembelajaran PAI berbasis proyek video Islami ini dilakukan melalui video Islami mengikuti desain model di bawah ini:

Tabel 2

Desain Model Pembelajaran PAI Berbasis Proyek Video Islami

\begin{tabular}{|c|c|c|c|c|}
\hline No & \multicolumn{2}{|c|}{ Tahap Pembelajaran } & Deskripsi Kegiatan & Petugas \\
\hline 1 & \multicolumn{2}{|c|}{$\begin{array}{l}\text { Pembukaan } \\
\text { pembelajaran }\end{array}$} & $\begin{array}{l}\text { Dosen menjelaskan tentang } \\
\text { proyek pembuatan video Islami } \\
\text { mencakup: } \\
\text { - pengertian, } \\
\text { - latar belakang, } \\
\text { - manfaat, } \\
\text { - karakter-karakter abad ke- } \\
21 \text { yang akan } \\
\text { dikembangkan yaitu jujur, } \\
\text { bertanggung jawab, } \\
\text { kreatif, kerja keras, } \\
\text { mandiri, komunikatif, } \\
\text { peduli sosial dan toleransi. }\end{array}$ & Dosen PAI \\
\hline 2 & \multirow{2}{*}{$\begin{array}{l}\text { Pembuatan } \\
\text { Video } \\
\text { Islami }\end{array}$} & \multirow{2}{*}{$\begin{array}{l}\text { 1. Tahap } \\
\text { Persiapan }\end{array}$} & $\begin{array}{l}\text { Menentukan topik/ tema yang } \\
\text { akan dibahas dan dituangkan ke } \\
\text { dalam video Islami. }\end{array}$ & Mahasiswa \\
\hline 3 & & & $\begin{array}{l}\text { Membuat rancangan storyboard } \\
\text { video Islami dengan } \\
\text { mengelompokkan data-data yang } \\
\text { dibutuhkan termasuk musik/lagu } \\
\text { yang akan digunakan. }\end{array}$ & Mahasiswa \\
\hline
\end{tabular}




\begin{tabular}{|c|c|c|c|}
\hline 4 & & $\begin{array}{l}\text { Melakukan riset. Mengumpulkan } \\
\text { informasi/data tentang topik } \\
\text { video Islami dari berbagai } \\
\text { sumber: buku, majalah, } \\
\text { ensiklopedi, jurnal, browsing } \\
\text { internet, media sosial, dll }\end{array}$ & Mahasiswa \\
\hline 5 & \multirow{4}{*}{$\begin{array}{l}\text { 2. Tahap } \\
\text { Pembuatan } \\
\text { Video } \\
\text { Islami }\end{array}$} & $\begin{array}{l}\text { Menulis narasi/ naskah video } \\
\text { Islami. Narasi untuk video } \\
\text { slideshow, naskah untuk video live } \\
\text { (rekaman). }\end{array}$ & Mahasiswa \\
\hline 6 & & $\begin{array}{l}\text { Pencarian gambar/ilustrasi untuk } \\
\text { setiap narasi atau perekaman } \\
\text { gambar sesuai dengan naskah } \\
\text { (video live) }\end{array}$ & Mahasiswa \\
\hline 7 & & $\begin{array}{l}\text { Editing. Menyatukan dan } \\
\text { menyusun informasi/ data/ } \\
\text { gambar/ rekaman terbaik dan } \\
\text { terpilih ke dalam aplikasi editor } \\
\text { video }\end{array}$ & Mahasiswa \\
\hline 8 & & $\begin{array}{l}\text { Sound Editing. Memasang musik } \\
\text { atau suara pada video Islami } \\
\text { sebagai tahap akhir pembuatan } \\
\text { video Islami }\end{array}$ & Mahasiswa \\
\hline 9 & \multirow{6}{*}{$\begin{array}{l}\text { 3. Tahap } \\
\text { Konsultasi } \\
\text { dan Revisi } \\
\text { Video }\end{array}$} & $\begin{array}{l}\text { Konsultasi ke-1 dengan dosen } \\
\text { PAI }\end{array}$ & $\begin{array}{l}\text { Dosen PAI, } \\
\text { Mahasiswa }\end{array}$ \\
\hline 10 & & $\begin{array}{l}\text { Revisi video Islami sesuai dengan } \\
\text { masukan dan arahan dari dosen } \\
\text { PAI }\end{array}$ & Mahasiswa \\
\hline 11 & & $\begin{array}{l}\text { Konsultasi ke- } 2 \text { dengan dosen } \\
\text { PAI }\end{array}$ & $\begin{array}{l}\text { Dosen PAI, } \\
\text { Mahasiswa }\end{array}$ \\
\hline 12 & & $\begin{array}{l}\text { Revisi ke- } 2 \text { sesuai dengan } \\
\text { masukan dan arahan dari dosen } \\
\text { PAI }\end{array}$ & Mahasiswa \\
\hline 13 & & $\begin{array}{l}\text { Konsultasi ke-3 dengan dosen } \\
\text { PAI }\end{array}$ & $\begin{array}{l}\text { Dosen PAI, } \\
\text { Mahasiswa }\end{array}$ \\
\hline 14 & & $\begin{array}{l}\text { Revisi ke- } 3 \text { sesuai dengan } \\
\text { masukan dan arahan dari dosen } \\
\text { PAI }\end{array}$ & Mahasiswa \\
\hline
\end{tabular}




\begin{tabular}{|c|l|l|l|l|}
15 & $\begin{array}{l}\text { 4. Tahap } \\
\text { Pelaporan }\end{array}$ & $\begin{array}{l}\text { Pengumpulan video akhir dan } \\
\text { presentasi }\end{array}$ & Mahasiswa \\
\hline \multirow{3}{*}{16} & Penutupan pembelajaran & $\begin{array}{l}\text { Dosen memberikan klarifikasi } \\
\text { nilai, penggalian nilai atau refleksi } \\
\text { nilai dari proses pembuatan video } \\
\text { Islami serta dari hasil video-video } \\
\text { Islami karya mahasiswa }\end{array}$ & Dosen PAI \\
& &
\end{tabular}

Langkah-langkah implementasi model sebagai berikut: di bagian pembukaan pembelajaran dosen PAI menjelaskan pengertian model, latar belakang model, manfaat model serta karakter-karakter yang diintegrasikan dalam model pembelajaran ini meliputi karakter jujur, bertanggung jawab, kreatif, kerja keras, mandiri, komunikatif, peduli sosial dan toleransi. Di bagian pembukaan pembelajaran ini, dosen juga membagi mahasiswa ke dalam beberapa kelompok. Setelah kelompok terbentuk maka dimulailah proses pembuatan video Islami yang terbagi ke dalam 4 tahap yaitu pertama, tahap persiapan membuat video; kedua, tahap pembuatan video; ketiga, tahap konsultasi dan revisi; dan keempat adalah tahap pelaporan. Setelah semua proses pembuatan video Islami tersebut selesai maka terakhir adalah bagian penutup pembelajaran. Di bagian penutup pembelajaran ini dosen PAI memberikan klarifikasi/refleksi nilai terhadap aktivitas yang telah dilakukan dan terhadap videovideo Islami yang dihasilkan oleh mahasiswa.

Dalam proses pembuatan video Islami yang memakan waktu cukup panjang yaitu selama 6 pekan, banyak nilai-nilai karakter yang terbangun dalam diri mahasiswa. Untuk bisa menghasilkan sebuah video Islami yang menarik, informatif dan bermakna tentunya tidak mudah, setiap kelompok harus bekerja sama, bekerja keras dan bekerja cerdas. Revisi video Islami yang dilakukan beberapa kali semakin mengasah keterampilan mahasiswa menggunakan aplikasi editor video sekaligus juga menguji sikap mental dan daya juang mereka.

Lebih jelasnya karakter-karakter yang terbangun melalui model pembelajaran PAI berbasis proyek video Islami ini adalah sebagai berikut:

a. Kejujuran. Kejujuran mahasiswa sangat ditekankan selama pembuatan video Islami. Video Islami yang mereka hasilkan haruslah benar-benar karya mereka sendiri bukan hasil karya orang lain ataupun plagiat dari video karya orang lain. Ketidak jujuran akan berakibat fatal pada nilai akhir mereka.

b. Tanggung jawab. Tanggung jawab mahasiswa juga ditumbuhkan selama pembuatan video Islami yaitu tanggung jawab untuk menyelesaikan tugas video Islami dengan baik dan mampu mengumpulkannya pada waktu yang ditetapkan. Video-video Islami yang mereka buat juga merupakan bentuk tanggung jawab mereka sebagai agent social of change.

c. Kreatif. Jiwa kreatif mahasiswa sudah pasti sangat terasah selama pembuatan video Islami. Video yang menarik, informatif dan bermakna hanya tercipta dari mahasiswa-mahasiswa yang berdaya kreativitas tinggi. Tanpa daya kreativitas tinggi maka yang tercipta 
hanya sebuah video yang biasa saja, monoton dan bahkan membosankan untuk ditonton. Selama pembuatan video Islami ini jiwa kreatif mahasiswa dikembangkan semaksimal mungkin.

d. Kerja keras. Pembuatan video Islami juga menuntut kerja keras dan keaktifan mahasiswa. Membuat rancangan awal video (video storyboard), mencari data dan fakta terkait topik yang diangkat dalam video, memilih musik, melakukan shooting/rekaman, kemudian mengolah semua informasi tersebut ke dalam aplikasi editor video hingga menghasilkan sebuah video yang menarik dan bermakna, ini semua membutuhkan waktu, pikiran, dana serta tenaga yang tidak sedikit. Belum ditambah proses konsultasi dan revisi berulang kali yang terkadang mahasiswa harus merombak total konsep videonya, semua proses tersebut hanya bisa dilakukan oleh mereka yang mampu bekerja keras serta memiliki kemauan dan daya juang tinggi.

e. Mandiri. Mandiri merupakan karakter yang juga terbangun dalam model ini. Semua proses pembuatan video Islami sejak persiapan, editing hingga pelaporan dan presentasi dilakukan setiap kelompok secara mandiri. Di dalam sebuah kelompok tentunya ada juga pembagian tugas di antara anggota-anggotanya yang menuntut setiap individu melaksanakan tugasnya secara mandiri. Sebuah video yang bagus adalah hasil dari kemandirian setiap individu dalam kelompok tersebut.

f. Komunikatif. Selama proses pembuatan video Islami setiap kelompok akan banyak berdiskusi dalam menentukan berbagai hal, seperti dalam membuat konsep video, storyboard video, membuat narasi/naskah, memilih gambar, musik video dll. Setiap anggota kelompok tentunya memiliki ide dan pendapatnya masing-masing. Disini mahasiswa dilatih untuk komunikatif yaitu mampu menyampaikan ide dan pendapatnya dengan baik dan lancar serta mudah dimengerti dan diterima oleh orang lain. Kemudian ketika mahasiswa tidak setuju dengan pendapat temannya, dia juga mampu menyampaikan ketidak setujuannya secara tepat dan tidak menyinggung perasaan temannya tersebut, sehingga kekompakan kelompok tetap terjaga dengan baik.

g. Peduli sosial. Jiwa peduli sosial juga terbangun selama pembuatan video Islami ini. Tentunya dalam sebuah kelompok, kemampuan dan kecerdasan para anggotanya berbeda-beda. Disini mahasiswa dilatih untuk saling peduli satu sama lain. Dalam kondisi tertentu tidak menutup kemungkinan ada anggota kelompok yang belum mampu melaksanakan tugasnya dengan baik, disini mahasiswa dilatih untuk mau memberi bantuan dan dukungan kepada temannya yang membutuhkan. Bahkan dalam kondisi tertentu mahasiswa dengan suka rela mau melakukan pekerjaan temannya.

h. Toleransi. Karakter toleransi juga ditumbuhkan selama pembuatan video Islami, yaitu mahasiswa dilatih untuk mampu mendengarkan dan menghormati pendapat temannya. Jika memang pendapat temannya yang terbaik maka dia siap menerimanya dengan lapang dada. Saat terjadi perbedaan pendapat atau keinginan bahkan konflik di antara anggota 
kelompok maka bagaimana mereka mampu mengatasi hal tersebut dengan baik, mampu menekan egonya dan mengutamakan kebaikan bersama, sehingga bisa tetap fokus pada satu tujuan yang mereka inginkan yaitu menciptakan sebuah video Islami yang menarik, informatif dan bermakna serta bisa bermanfaat bagi masyarakat luas.

Pengembangan karakter dalam model pembelajaran ini juga dilakukan melalui materi PAI. Karakter-karkater yang menjadi fokus dalam penelitian ini yaitu jujur, bertanggung jawab, kreatif, kerja keras, mandiri, komunikatif, peduli sosial dan toleransi sekaligus juga dijadikan sebagai tema/topik video yang diproduksi oleh mahasiswa. Dengan hal ini diharapkan karakter dapat terbangun dalam diri mahasiswa mencakup moral knowing dan moral acting.

Selanjutnya dalam pengembangan model ini dilakukan uji efektifitas model. Untuk menganalisis efektifitas model ini digunakan model pretest-postest design dengan teknik analisis data uji Wilcoxon signed-rank. Hasil uji efektifitas model dapat dilihat dalam tabel 3 di bawah ini:

Tabel 3

Hasil Ujicoba terbatas 


\begin{tabular}{|c|c|c|c|c|c|}
\hline \multirow[b]{2}{*}{ Kelas } & \multirow[b]{2}{*}{ Jenis Nilai } & \multicolumn{2}{|c|}{ Hasil Uji Normalitas } & \multicolumn{2}{|c|}{ Hasil Uji Wilcoxon } \\
\hline & & Nilai Sig. & Interpretasi & $\begin{array}{c}\text { Nilai Asymp. } \\
\text { (2-tailed) }\end{array}$ & Interpretasi \\
\hline \multirow[b]{2}{*}{ PTIK } & Pretest & 0,2 & $\begin{array}{c}\text { berdistribusi } \\
\text { normal }\end{array}$ & \multirow[b]{2}{*}{0,000} & \multirow[b]{2}{*}{$\begin{array}{c}\text { ada perbedaan } \\
\text { signifikan }\end{array}$} \\
\hline & Posttest & 0,009 & $\begin{array}{c}\text { tidak } \\
\text { berdistribusi } \\
\text { normal }\end{array}$ & & \\
\hline \multirow{2}{*}{$\begin{array}{l}\text { Pendidikan } \\
\text { Matematika }\end{array}$} & Pretest & 0,023 & $\begin{array}{c}\text { tidak } \\
\text { berdistribusi } \\
\text { normal }\end{array}$ & \multirow{2}{*}{0,000} & \multirow{2}{*}{$\begin{array}{c}\text { ada perbedaan } \\
\text { signifikan }\end{array}$} \\
\hline & Posttest & 0,000 & $\begin{array}{c}\text { tidak } \\
\text { berdistribusi } \\
\text { normal }\end{array}$ & & \\
\hline \multirow{2}{*}{$\begin{array}{l}\text { Pendidikan } \\
\text { Tata Busana }\end{array}$} & Pretest & 0,005 & $\begin{array}{c}\text { tidak } \\
\text { berdistribusi } \\
\text { normal }\end{array}$ & \multirow[t]{2}{*}{0,000} & \multirow{2}{*}{$\begin{array}{c}\text { ada perbedaan } \\
\text { signifikan }\end{array}$} \\
\hline & Posttest & 0,17 & $\begin{array}{c}\text { berdistribusi } \\
\text { normal }\end{array}$ & & \\
\hline
\end{tabular}

Dari tabel di atas terlihat bahwa hasil dari pengujian terhadap ketiga kelas sampel ujicoba model semuanya menunjukkan hasil nilai Asymp. (2-tailed) < $\alpha$ maka Ho ditolak dan $\mathrm{Ha}$ diterima, bermakna terdapat perbedaan pengembangan karakter mahasiswa yang signifikan antara sebelum dan setelah model pembelajaran PAI berbasis proyek video Islami diterapkan di kelas sampel.
Karakter-Karakter Yang Terbangun Melalui Model Pembelajaran PAI Berbasis Proyek Video Islami

Selanjutnya perlu dilihat karakterkarakter apa saja yang terbangun secara efektif melalui model pembelajaran PAI berbasis proyek video Islami ini. Untuk mengetahui hal ini penulis menghitung $\mathrm{N}$ Gain score dari masing-masing karakter dengan membandingkan skor pretest dan posttest setiap karakter dari ketiga kelas sampel. Berikut ini adalah sebaran nilai pretest dan posttest dari masing-masing karakter.

Tabel 4

Sebaran Nilai Pretest dan Posttest Karakter 


\begin{tabular}{|l|c|c|c|}
\hline \multicolumn{1}{|c|}{ Nilai Karakter } & Skor Pretest & Skor Postest & Skor Ideal \\
\hline Jujur & 454 & 480 & 570 \\
Bertanggung jawab & 447 & 477 & 570 \\
Kreatif & 368 & 479 & 570 \\
Kerja keras & 393 & 471 & 570 \\
Mandiri & 385 & 449 & 570 \\
Komunikatif & 404 & 444 & 570 \\
Peduli sosial & 426 & 463 & 570 \\
Toleransi & 432 & 454 & 570 \\
Keterampilan memanfaatkan & 364 & 481 & 570 \\
teknologi informasi untuk & 360 & 476 & 570 \\
berkreativitas Islami & & & \\
Keterampilan berdakwah virtual & 360 & \\
\hline
\end{tabular}

Dari tabel 4 di atas dapat dilihat nilai skor pretest tertinggi ada pada karakter jujur sebesar 454, dan nilai skor pretest terendah ada pada keterampilan berdakwah virtual yaitu sebesar 360. Sedangkan untuk posttest, nilai skor tertinggi ada pada keterampilan memanfaatkan teknologi informasi untuk berkreativitas Islami sebesar 481, dan nilai skor posttest terendah ada pada karakter komunikatif sebesar 444 .

Selanjutnya dihitung N-Gain score karakter dengan berpedoman pada interpretasi N-Gain di bawah ini.

Tabel 5

Interpretasi N-Gain (g)

\begin{tabular}{|c|c|}
\hline Besar $\mathbf{g}$ & Interpretasi \\
\hline $\mathrm{g}>0,7$ & Tinggi \\
\hline $0,3 \leq \mathrm{g} \leq 0,7$ & Sedang \\
\hline $\mathrm{g}<0,3$ & Rendah \\
\hline
\end{tabular}

Berdasarkan tabel Interpretasi N-Gain, maka hasil N-Gain karakter dapat dilihat dalam tabel berikut. 
Tabel 6

N-Gain Score Karakter

\begin{tabular}{|l|c|c|}
\hline \multicolumn{1}{|c|}{ Jenis Karakter } & N-Gain & Interpretasi \\
\hline Jujur & 0.22 & rendah \\
Tanggung jawab & 0.24 & rendah \\
Kreatif & 0.55 & sedang \\
Kerja keras & 0.44 & sedang \\
Mandiri & 0.35 & sedang \\
Komunikatif & 0.24 & rendah \\
Peduli sosial & 0.26 & rendah \\
Toleransi & 0.16 & rendah \\
Memanfaatkan TIK untuk berkreativitas Islami & 0.57 & sedang \\
Kemampuan Berdakwah virtual & 0.55 & sedang \\
\hline
\end{tabular}

Efek positif dari model

Dari tabel di atas diketahui bahwa semua karakter mengalami peningkatan meskipun pencapaiannya berbeda-beda. Secara umum N-Gain karakter berada pada dua kategori yaitu kategori sedang dan rendah. Karakter yang berada pada kategori sedang ada sebanyak lima karakter yaitu karakter kreatif, kerja keras, mandiri, keterampilan memanfaatkan TIK untuk berkreativitas Islami dan keterampilan berdakwah virtual. Adapun karakter yang berada pada kategori rendah ada sebanyak lima karakter yaitu jujur, bertanggung jawab, komunikatif, peduli sosial dan toleransi.

Berdasarkan hal ini maka dapat dimaknai model pembelajaran PAI berbasis proyek video Islami di Universitas Negeri Medan efektif membangun karakter mahasiswa khususnya karakter kreatif, kerja keras dan mandiri, serta keterampilan memanfaatkan teknologi informasi untuk berkreativitas Islami dan berdakwah virtual. pembelajaran PAI berbasis proyek video Islami terhadap pembangunan karakter mahasiswa sesuai dengan adagium umum yaitu "Saya mendengar dan saya lupa; saya melihat dan saya ingat; saya mencoba dan saya mengerti", yang mengisyaratkan bahwa keterlibatan secara aktif merupakan hal yang sangat penting dalam membangun pemahaman peserta didik. Proyek pembuatan video Islami ini jelas sangat melibatkan mahasiswa dalam aktivitas belajar baik secara fisik maupun mental, karena sejak mulai perencanaan, pembuatan konsep, pencarian data, proses editing video hingga pelaporan, mahasiswa banyak berpikir dan bergerak aktif. Jika dilihat dari teori belajar hal inilah yang sangat dianjurkan yaitu pembelajaran yang mampu melibatkan multi indera bahkan juga ikut melakukan. Semakin aktif peserta didik maka akan semakin menarik dan bermakna pembelajaran tersebut di hati peserta didik karena pengalaman yang multi indera, dramatis, tidak biasa atau kuat 
secara emosional akan diingat jauh lebih lama daripada pengalaman rutin yang biasa (Ginnis, 2008). Hasil positif dari model pembelajaran PAI berbasis proyek video
Islami ini juga bisa dinalisis dari teori "kerucut pengalaman" Edgar Dale di bawah ini.

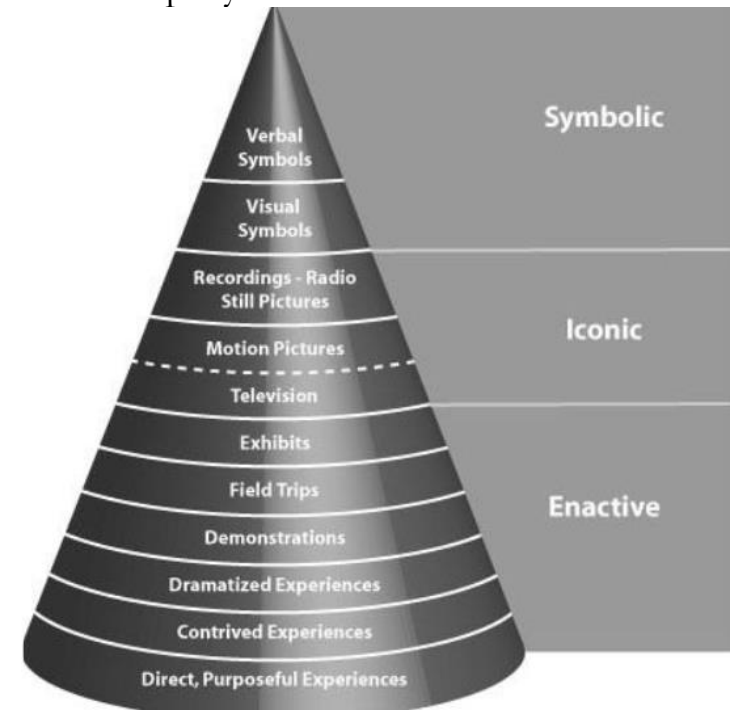

Gambar 1. Kerucut Pengalaman Edgar Dale

Berdasarkan kerucut pengalaman Edgar Dale di atas, terlihat bahwa proses pembelajaran langsung lebih efektif daripada hanya melalui pengamatan. Dalam pembelajaran PAI berbasis proyek video Islami ini mahasiswa memperoleh pengalaman pembelajaran yang bermakna karena mereka melakukan serangkaian aktivitas belajar serta mampu menghasilkan produk tangible berupa video Islami yang menarik, informatif dan bermakna.

\section{KESIMPULAN}

Pengembangan model pendidikan karakter terintegrasi dalam pembelajaran PAI di Perguruan Tinggi sangat penting untuk dilakukan, khususnya pengintegrasian karakter-karakter yang dibutuhkan di abad ke-21. Beberapa cara untuk mengembangkan model pendidikan karakter terintegrasi dalam pembelajaran PAI yaitu: 1. menyesuaikan model pembelajaran PAI dengan karakteristik, daya serap dan tingkat kemampuan mahasiswa yang sudah jauh berkembang, 2 . menerapkan metode dan strategi pembelajaran inovatif yang mengaktifkan mahasiswa. 3. memberikan pengalamanpengalaman bermakna yang bermuatan karakter selama proses pembelajaran PAI. 4. memasukkan karakter sebagai materi pembelajaran PAI.

Pengintegrasian pendidikan karakter melalui model pembelajaran PAI berbasis proyek video Islami terbukti efektif membangun karakter mahasiswa, terutama karakter kreatif, kerja keras dan mandiri, serta membangun keterampilan berkreativitas Islami dan berdakwah virtual.

\section{DAFTAR PUSTAKA}


Borg, W. R., \& Gall, M. D. (1989). Educational Research: An Introduction. New York: Longman.

Bronson, M. S. (1998). The Role of Civic Education. Calabasas: Center For Civic Education.

Budimansyah, D. (2014). Perancangan Pembelajaran Berbasis Karakter. Bandung: Widya Aksara Press.

Buol, R. . (2018). DATA: Indonesia Peringkat Kelima Pengguna Internet Dunia.

Chaplin, C. . (1989). Kamus Lengkap Psikologi (K. Kartono, Ed.). Jakarta: CV Rajawali.

Dulwahab, E. (2010). Dakwah di Era Konvergensi Media. Jurnal Ilmu Dakwah, 4(16), 19-34.

Giddens, A. (1990). The Consequences of Modernity. California: Stanford University Press.

Ginnis, P. (2008). Trik \& Taktik Mengajar. Strategi Meningkatkan Pencapaian Pengajaran di Kelas. Jakarta: Indeks.

Inilah Data Pengguna Internet di Indonesia 2018, 49\% Penggila Medsos. (2018).

Kementerian Pendidikan dan Kebudayaan. (2017). Konsep dan Pedoman Penguatan Pendidikan Karakter. Jakarta: Kementerian Pendidikan dan Kebudayaan.

Kementerian Pendidikan Nasional. (2010). Desain Induk Pendidikan Karakter. Jakarta: Kementerian Pendidikan Nasional.

Lickona, T. (1992). Educating for Character: How Our School Can Teach Respect and Responsibility. New York, Toronto, London, Sydney, Auckland: Bantam Books.

Lickona, T. (2004). Character Matters: How to Help Our Children Develop Good
Judgement, Integrity, and Other Essential Virtues. New York: Simon \& Schusters, Inc.

Miles, M. B., \& Hubberman, A. M. (1992). Analisis Data Kualitatif. Jakarta: UI Press.

Mulyana, R. (2013). Model Pembelajaran Nilai Melalui Pendidikan Agama Islam. Jakarta: Saadah Pustaka Mandiri.

Nurudin. (2007). Merumuskan strategi pembelajaran nilai (keagamaan) dalam pendidikan Islam'. Edukasi Jurnal Penelitian Pendidikan Agama dan Keagamaan, 5(1), 55-73.

Sagala, S. (2007). Konsep dan Makna Pembelajaran: Untuk Membantu Memecabkan Problematika Belajar dan Mengajar. Bandung: Alfabeta.

Sholihin, B. (2018). Indonesia Digital Landscape 2018. Diambil dari Slideshare website: https:/ /www.slideshare.net/rumah ide/indonesia-digital-landscape2018

Syahidin, Alma, B., Rahmat, M., AF, A. T. S., \& Abdussalam, A. (2009). Moral dan Kognisi Islam. Bandung: Alfabeta.

Tan, C. (2011). Islamic Education and Indoctrination. New York: Routledge. Yousif, A. F. (2001). Information Technology in The 21st Century: An Islamic Perspective. International Conference on Information Systems and Islam. Malaysia: IIUM. 